Review Article

\title{
Thalassemia an update: molecular basis, clinical features and treatment
}

\author{
Kaveh Tari ${ }^{1}$, Pooya Valizadeh Ardalan ${ }^{2}$, Mahnoosh Abbaszadehdibavar ${ }^{3}$, Amir atashi $^{4}$, Ali Jalili ${ }^{5}$, Maryam \\ Gheidishahran $^{6}$
}

\begin{tabular}{l} 
ARTICLE INFO \\
\hline Article History: \\
Received 4 January 2018 \\
Revised 10 January 2018 \\
Accepted 10 January 2018 \\
Published online 15 January 2018
\end{tabular}

Keywords:

Thalassemia; Molecular basis,

Clinical features, Treatment

${ }^{I}$ Cancer and Immunology Research Center, Kurdistan University of Medical Sciences, Sanandaj, Iran ${ }^{2}$ Student Research committee, Kurdistan University of Medical Sciences, Sanandaj, Iran ${ }^{3}$ Department of Hematology, Faculty of medical science, Tarbiat Modares University, Tehran, Iran ${ }^{4}$ Stem Cell and Tissue Engineering Research Center, Shahroud University of Medical Sciences, Shahroud, Iran ${ }^{5}$ Cancer and Immunology Research Center, Kurdistan University of Medical Sciences,

Sanandaj, Iran ${ }^{6}$ Department of Hematology and Blood Transfusion, School of Allied Medical

Science, Iran University of Medical Sciences,

Tehran., Iran

*Correspondence:

Kaveh Tari, Cancer and Immunology Research

Center, Kurdistan University of Medical

Sciences, Sanandaj, Iran

Email:k.tari@modares.ac.ir

\begin{abstract}
Thalassemia are a group of inherited blood disorders caused by the decrease or absence of beta-globin chain synthesis will be determined with decrease in erythrocyte hemoglobin, decreased production of erythrocytes and anemia. More thalassemia is inherited as recessive autosomal. According to this fact that which one of the chains are involved, they invide into two type including alpha and beta thalassemia, which each of them including several types. Thalassemia major is more extensive and patient needs to blood transfusion, but thalassemia minor is slight. The most important problem in this patient include iron overload, cardiac arrhythmia, hepatitis, osteoporosis and endocrine disorder however there are typical signs and symptoms of anemia. Treatment including Change of expression and production of $\mathrm{HbF}$, Hematopoietic stem cell transplantation and Maintenance Treatment such as chelators therapy, Induction of fetal hemoglobin production by using Hydroxia urea, use of immunomodulator agents and Molecular Therapy by targeting of genes involving in $\mathrm{HbF}$ expression.in this article we review the thalassemia disorder and discuss on molecular basis, clinical features and treatment.
\end{abstract}

\section{Introduction:}

$\mathrm{T}$ halassemia is a Greek word that taken from two words, Thalassa means Sea and Emia means blood, thus called Mediterranean anemia or Cooley's anemia, anemia in Persian. Thalassemia is a congenital hemolytic disease that inherited according to Mendel's laws. The first an American scientist named Dr. Cooley defined it's to other in1925. In this synthesis and defective $\mathrm{Hb}$ produce. In erythroid precursors additional chains don't pair together, this synthesis that this leads unbalanced $\mathrm{Hb}$ chain damage and lyse cells (1). If beta chain is defective, called beta thalassemia and if alpha chain is defective, called alpha thalassemia. Beta-thalassemia syndromes are a group of hereditary blood disorders characterized by reduced or absent beta-globin chains expression that 
Thalassemia an update

decreases the $\mathrm{Hb}$ synthesis and ultimately reduce the production of erythrocytes and lead to anemia (2).

\section{Epidemiology}

Beta thalassemia is prevalent in countries around the Mediterranean, the Middle East, parts of Central Asia, India, southern China and the northern states

Africa and South America. The prevalence of the most carriers is seen in Cyprus (14\%), Saardinia (10\%) and Southeast regions of Dinia (10\%) and Southeast Asia. A high frequency of beta thalassemia gene in these areas due to natural selection against malaria is Plasmodium falciparum (3). The immigrant populations and marriage between different ethnic groups causes thalassemia to be common between all countries, even countries in northern Europe where thalassemia did not previously there. It is estimated that about 1.5 percent of the world population are thalassemia carriers, with about 60000 people marked the birth annually; the majority of other are in developing countries (4). According to the Thalassemia International Federation assessment, only about 200000 patients with thalassemia major are alive and registered and regularly receive treatment in all over world (5). Our country has a large number of cases is affected beta-thalassemia major; its prevalence is various in different geographical areas. The highest prevalence of $\beta$-thalassemia has been reported around the Caspian Sea and the Persian Gulf by more than $10 \%$. The prevalence of this disorder in other areas is between 8-4\% (6).

\section{Etiology}

More than 200 mutations have been reported, the majority of mutations point are in beta-globulin gene areas. Beta globin gene deletions are not common; $\beta$ globin chain reduce or don't product due to $\beta$-globin gene mutations. A mutation causes a defect in the promoter activity, processing of RNA, translated or reduced instability of MRNA. Despite the great variety of mutations, only 20 of them result $80 \%$ of thalassemia $(7,8)$. Gene modulators defined as genetic variants, which lead to differences in diseases phenotype. In homozygous beta thalassemia early genetic modifiers are effective clinical severity, which reduces the imbalance of globin chains, so they cause milder form of thalassemia. To inheritance of alpha thalassemia simultaneous or some genetic factors causing sustain production globin chains, $(\mathrm{HbF})$ in adults (9).

\section{Various forms of thalassemia}

Thalassemia can be divided into two types, alpha thalassemia and beta thalassemia (Table 1). Given that the prevalence of beta thalassemia major patients is greater than alpha thalassemia patients in Iran respectively, therapeutic purposes focused on beta thalassemia major.

\section{Alpha thalassemia}

Alpha thalassemia is one of the most common hemoglobin disorders in the world which is more prevalent in parts of Africa, Southeast Asia and the Middle East (14). Alpha globin gene cluster has a length of about $30 \mathrm{~kb}$ on chromosome 16 and inherited by four gene locus. Alpha thalassemia studied; show that the disease is largely due to the removal of changeable pieces from one or two alpha genes at the molecular level (15). Two fragments of alpha globin gene $\alpha_{2}$ and $\alpha_{1}$ in analog two loci on the same chromosome replaced very similar to the two units are $4 \mathrm{~kb}$, the same sequences are separated by nonidentical elements (16). In fact recombination between alleles that could remove genes that to be one of the mechanisms responsible for decreasing the alpha chain synthesis in alpha thalassemia. The outcome disease severity depends on the number of genes involved in the final. If patient to be missing one of alpha gene release, $\alpha^{+} h t a 1$, if missed two alpha genes transvers release homologous $\alpha^{+} h t a 1^{+}$that in this form patient are also asymptomatic or associated with intermediate anemia but most of them have microcytic red blood cells (MCV <80fL). In case remove three alpha genes, this is hemoglobin $\mathrm{H}$ disease that patient shows intermediate thalassemia with intermediate anemia (17). Whereas, deletion of each four genes lead to Hydrops Fetalis disease that is associated with intrauterine fetal death. More than 95\% of alpha thalassemia is kind of elimination. The most common type of elimination alpha that the two genes are deleted referred to Southeast Asian variety (- -SEA), Mediterranean (- - MED), ( $\alpha$ ) 20.5) and the Philippines (- - FIL). The most common single gene is removed, referred to (- $\alpha$ 3.7) and (- $\alpha$ 4.2) (18).

\section{Beta thalassemia}

Thalassemia syndromes are a group of inherited blood disorders caused by the decrease or absence of betaglobin chain synthesis will be determined with decrease in erythrocyte hemoglobin, decreased production of erythrocytes and anemia. More thalassemia is inherited as recessive autosomal. According to the clinical and laboratory diagnostic, three types of beta thalassemia defined: Beta thalassemia major, Beta thalassemia intermedia and Beta thalassemia minor (19). 
Table 1: Different types of thalassemia

\begin{tabular}{|c|c|c|c|c|}
\hline Molecular genetic & Clinical symptom & Genotype & Type of thalassemia & \\
\hline \multirow[t]{4}{*}{$\begin{array}{l}\text { Mainly point mutations that lead to } \\
\text { defect in transcription. Processing or } \\
\text { translocation of mRNA beta globin } \\
\text { gene. }\end{array}$} & $\begin{array}{l}\text { Severe and needed to regular } \\
\text { blood transfusion }\end{array}$ & $\begin{array}{l}{ }_{/} \beta^{\circ} \beta^{\circ} \\
{ }_{\beta} \beta^{+} \beta^{+} \\
{ }_{\beta} \beta^{\circ} \beta^{+}\end{array}$ & $\begin{array}{l}\text { Beta thalassemia } \\
\text { Beta thalassemia } \\
\text { major }\end{array}$ & (10) \\
\hline & \multicolumn{2}{|l|}{$\begin{array}{l}\text { Intermediate to severe } \\
\text { They don't need to blood } \\
\text { transfusion regularity }\end{array}$} & $\begin{array}{l}\text { Beta thalassemia } \\
\text { intermedia }\end{array}$ & (11) \\
\hline & $\begin{array}{l}\text { Asymptomatic } \\
\text { Slight anemia occasionally }\end{array}$ & $\beta / \beta 0 \triangleleft \beta / \beta+$ & $\begin{array}{l}\text { Beta thalassemia } \\
\text { minor }\end{array}$ & (12) \\
\hline & \multicolumn{3}{|c|}{$\beta / \beta 0$ ، $\beta / \beta+$} & \\
\hline \multirow[t]{4}{*}{$\begin{array}{l}\text { Mainly happen deletion of alpha } \\
\text { globin gene }\end{array}$} & Asymptomatic & $-\alpha / \alpha \quad \alpha$ & $\begin{array}{l}\text { Alpha thalassemia } \\
\text { Silence carrier }\end{array}$ & \\
\hline & & $\begin{array}{l}\text { (Asiatic) -- / } \alpha \alpha \text { ، } \\
\text { American ‘(Asiatic }-\alpha-/ \alpha \\
\text { dark-skinned) }\end{array}$ & $\begin{array}{l}\text { Alpha thalassemia } \\
\text { minor }\end{array}$ & (13) \\
\hline & $\begin{array}{l}\text { Intermediate to severe } \\
\text { Similar to thalassemia intermedia }\end{array}$ & $--/-\alpha$ & $\begin{array}{l}\text { Hemoglobin } \mathrm{H} \\
\text { disease }\end{array}$ & \\
\hline & $\begin{array}{l}\text { intrauterine fetal death or birth of } \\
\text { dead fetal }\end{array}$ & -- / -- & Hydrops Fetalis & \\
\hline
\end{tabular}

\section{Beta thalassemia major}

Thalassemia major clinical symptoms appear between 6 and 24 month after birth. Babies with thalassemia major will suffer nutritional problems, diarrhea, irritability, frequent bouts of fever, abdominal distention and a progressive increase in the size of spleen and liver (20). So skeletal changes including changes in the long bones of the leg and craniofacial changes is seen in patients. In fact a regular blood transfusions can maintain hemoglobin levels in the range of 5.9 to 5.10 grams per deciliter in patients and grow up is close to normal until about 10 to 12 years (21). The patients, who receive blood, may involve complications of iron overload in the tissues. Complications of iron overload in children include delayed growth and sexual maturation. The next complications of iron overload including heart damage Myocardiopathy and rarely, arrhythmia, liver (fibrosis and cirrhosis), endocrine glands (diabetes), hypogonadism, parathyroid and thyroid insufficiency (22). Complications consequent contamination blood transfusion cause transmit hepatitis B virus that and C, human immunodeficiency virus. The risk of hepatocellular carcinoma in patients with infectious liver and iron overload are greater eventually these patients die due to cirrhosis of the heart muscle caused by iron deposition in the heart $(23,24)$.

\section{Beta-thalassemia intermedia}

Symptoms of people beside thalassemia major are determined later, they have milder anemia and do not need to regular blood transfusion. At one end of the spectrum of clinical symptoms will be displayed between the ages of 2 to 6 years in these patients (10). Although, they can survive without regular blood transfusions. But suffer from a lack of sufficient growth. At the other end of the spectrum of disease, does not show specific symptoms except mild anemia into adulthood. In general, patients with thalassemia intermedia, hypertrophy and increased erythroid mass and the possibility of extra medullary hematopoiesis are common for overcome the chronic anemia (25). Extra medullary erythropoiesis may cause neurological damage such as pressure on the spinal cord and vertebral column. Foot ulcers and incidence of thrombosis are more common in thalassemia intermedia compared to the thalassemia major, especially after splenectomy (26).

\section{Beta-thalassemia minor}

Thalassemia minor carriers except for mild anemia are clinically asymptomatic, this type of thalassemia is heterozygous state that only one allele of the $\beta$ gene defect on chromosome 11 and the other allele is 
Thalassemia an update

normal. The disease can be inherited by $\beta^{0}$ gene (nonsynthetic) and $\beta^{+}$gene (synthesis reduced) (12).

\section{Pathophysiology}

Absence or reduce the amount of beta-globin chains cause relative increase of alpha globin chains that are deposited in erythroid precursors in the bone marrow, leading to premature death and therefore an ineffective erythropoiesis. The mutation that reduces the production of beta globin chain is located on chromosome 11. Hemolytic anemia in the environment that causes thalassemia occurs when the insoluble globin chains can cause damage peripheral erythrocyte membrane (27). The alpha inclusions and degradation products are local for reactive oxygen species (ROS) (17). When erythrocytes enter peripheral blood due to deposition of alpha tetramers and accumulation of band 3 protein on their surface opsonized by $\mathrm{IgG}$ and complement and removed by macrophages and destroyed in the spleen. In these patients, ineffective erythropoiesis lead to anemia and also anemia increase by destruction of peripheral erythrocytes in the spleen. On the other hand, anemia cause hypoxia and hypoxia condition lead to active Hypoxia - inducible factor (HIF) (28). HIF formed from two unit include aand $\beta$ that they divorce and inactive in normal oxygen pressure condition but, in hypoxia condition they connect together and active HIF. Activated HIF subsequently increased the EPO. Erythropoietin causes hyperplasia normoblastic and increase hematopoiesis 25 to 30 times with normal and expansion of hematopoietic bone marrow hematopoietic space. This increases the deformation of the bones. As well as long-term and severe anemia and increased of erythroid precursors leading to hepatosplenomegaly and extra medullary hematopoiesis (29). Erythropoiesis is way to generate mature cells of the hematopoietic stem cells. This process involves several stages of differentiation and proliferation of cells that impress specific expression of erythroid progenitor genes. The process of erythropoiesis occurs through the combined effects of the microenvironment bone marrow and growth factors that increase the survival, proliferation or differentiation of erythroid precursors and nuclear factors that regulate gene transcription. Erythrocyte production is driven by a complex network of transcription factors, which the GATA-1 gene is major gene in erythropoiesis that causes specific upregulation of erythroid genes such as the EPOR, Glycophorin A (GPA) and the globin chains. Proliferation and differentiation of erythroid cells to be positive or negative is strictly controlled to ensure the production of erythrocytes (30).

\section{Mutations and allelic variants of beta thalassemia}

Beta-thalassemia is a heterogeneous on molecular face. Since, have been identified more than 23 different types of molecular defect in the beta-globin gene (31). Decrease or lake of beta globin chain lead to increase free alpha globin chain that deposit in erythroid precursors in bone marrow so, cause destruction pre-maturation red blood cell and defective erythropoiesis. The degree of reduction globin chain is determined by beta globin gene mutation on chromosome 11.Different strategies classification of genotyping of individuals by categories beta globin gene and cloning of nucleotide sequence led to the identification of several new mutations in the Mediterranean, India, China and America's dark-skinned population $(32,33)$.

\section{A number of mutations have been reported in Iran}

Generally speaking, IVS -II-1 ( $\rightarrow$ A) is the most common mutation in Iran (33/9\%) of this Mediterranean mutation has high frequency in Iran beside the Mediterranean countries, which may suggest that slope downward East to West that Iran is the origin of this mutation $(34,35)$. IVS-I-110 (G $\rightarrow$ A) is One of the most common alleles of beta thalassemia in Mediterranean countries and, as expected, high frequency of this mutation in the North West of Iran near the Turkish Azerbaijani population has been found and its frequency is reduced in the south east of Iran. On the other hand IVS-I-5 $(\mathrm{G} \rightarrow \mathrm{A})$ is the most common mutation in the Indian subcontinent that is found with high frequency in South and South-East Iran, which is located near Pakistan. While have been found the low frequency of this mutation in the North West of the country. The presence of abundant and dissimilar mutations in Iranian population in category of globin gene, certainly can be as evidence for a method of formation of the population in the past (36).

\section{Positive regulation of erythropoiesis}

The process of erythropoiesis controlled through the combined effects of two major cytokines called stem cell factor (SCF) and EPO. SCF induces the proliferation, survival and reduction differentiation of primary erythroid progenitors and precursors beside basophilic erythroblast stage. EPO is responsible for the proper regulation of hemostatic number of erythrocytes by oxygen in tissues. Interaction between of erythropoietin and erythropoietin receptor leads to activation of JAK2, several signaling pathways involved in kinase Akt, PI3 and STAT5, which inhibits apoptosis, supporting the proliferation of 
Thalassemia an update

erythroid progenitors and maturation of erythrocytes $(37,38)$.

\section{Negative regulator of erythropoiesis through apoptosis}

Negative regulator of erythropoiesis is mainly due to cellular apoptosis, a fundamental mechanism for clearing cells that are potentially dangerous. Apoptotic programs realized by the family of proteases that dependent on cysteine and proprietary aspartate, called caspases $(39,40)$.

\section{Ineffective erythropoiesis in thalassemia}

Erythroid precursors are 5 to 6 times in thalassemia patients BM compared to healthy individuals, which is very early precursors and can be seen inhibition of maturation of erythroid in bone marrow, the more cells are seen pronormoblast. Ineffective erythropoiesis defined by suboptimal production of mature erythrocytes from immature cells erythroblast islands. So appears through accelerating the erythroid differentiation, maturation inhibition in polycromatophilic stage and death of erythroid progenitor stage $(41,42)$. Increased apoptosis is a key feature of ineffective erythropoiesis in beta thalassemia major, so in this case saw an increase in apoptosis erythroid progenitor in the bone marrow, but lymphoid and myeloid precursors don't have increased in apoptosis (43).

Despite a significant increase in apoptosis erythroid precursors in the bone marrow in Thalassemia Major, when we see smear of bone marrow, do not see a large addition in number of dead erythroblast. This condition due to cleared by macrophages in the bone marrow(44). Study of death of apoptotic receptor pathways suggests that the fas and fas ligand express in early and late stages of differentiation together. Both proteins downregulate in the bone marrow or spleen beta thalamic in proerythroblastic cells compared with healthy mice with, which downregulation of fas and fasL may be erythropoietic stress markers. Evidence of conflict inside pathway of apoptosis in thalassemia major doesn't specify to date (45).

\section{Problems and complications of Thalassemia}

Reduction of each globin chains production in Thalassemia, leading to disruption of the relationship between alpha and beta chains. Unpaired chain deposit in red blood cells and this is the beginning of thalassemia problems (44).

\section{Iron overload}

Many of problems create by iron overload and its destructive role in patients with thalassemia. Three main reasons for this phenomenon are considered: ineffective erythropoiesis, frequently blood transfusions and increasing the intestinal absorption of iron, the first and second due to excessive destruction of red blood cells and the latter due to chronic anemia. Addition of iron in thalassemia patients due to the, is the protein transferrin saturation as a carrier of iron in the body, as a result, free iron accumulates in the blood and body tissues, produce potentially harmful compounds in the body tissue $(46,47)$.

\section{Cardiac arrhythmia}

Heart disorders have been reported as the cause of death in $50 \%$ of patients with thalassemia (48). Two major structural mechanism and cardiac function in patients with thalassemia affects: the accumulation of iron overload in cardiac cells and an increase in cardiac output. The first mechanism causing the myocardial heart and hypertrophy disorders in the heart layers. Impaired function in left ventricular mainly due to this situation (49). Myocardial sensitivity to oxygen free radical resulting from free iron within the cell in this disorder, thus leads to diastolic dysfunction. The second mechanism caused by the presence of chronic anemia and hypoxia, increase of erythroid cells due to the body's reaction and increase of volume blood. This situation, heart regulate this condition by increase of output but this mechanism lead to pressuring to heart due to increase severity and measure of contraction. Subsequently the mechanism leads to increase pulmonary vascular resistance and consequently increase pressure of pulmonary and resulting right ventricular dysfunction $(50,51)$.

\section{Endocrine disorders}

Endocrine disorder is from iron overload problems in patients with thalassemia. The anterior pituitary is very sensitive to iron deposition in tissues. This sensitivity can cause serious disturbances in the synthesis and secretion of hormones (52). In the meantime, hypogonadism is the most common disorder has been observed in $70 \%$ of patients with thalassemia (53). In these patients, product and storage of thyroid hormones is much lower than in healthy people, which combined with delay in puberty, reproductive disorders and related factors (54). Other complications are reduction of growth access, which causes endocrine disorders involved in its development in patients with thalassemia. Delay or lack of growth during puberty leads to short stature. Other disorders include the primary hypothyroidism, hypoparathyroidism in the second decade of life, 
Thalassemia an update

decreased ability to build bone and other disorders, osteoporosis and diabetes, in these patients (55-57).

\section{Hepatitis}

Thalassemic patients receive long-term blood and blood products and are at risk of viral infection such as viral hepatitis. Despite hepatitis B vaccines for donors and thalassemic patients, the prevalence of these viral diseases among these patients is greatly reduced (58). But the lack of a vaccine for hepatitis $\mathrm{C}$, continuously, it's a greatly difficult among these patient.

\section{Osteoporosis}

Almost all thalassemic patients are suffering from this condition. The consequences of osteoporosis can be noted multiple fractures and severe bone pain. Since the mineral density of axial bone occurs faster than peripheral bone in adulthood, lumbar vertebra spine are affected more than other sectors $(59,60)$.

\section{Treatment}

\section{Change of expression and production of $\mathrm{HbF}$}

Replacing $\mathrm{HbA}$ to $\mathrm{HbF}$ formed short time after birth in human due to change production gamma gene to beta-globin gene is. This process requires specific class changes in the expression or function of transcription factors and reconstruction chromosomes activities in gene repression expression of gamma globin and induce beta globin gene (61). Increase $\mathrm{HbF}$ able to improve the clinical symptoms in patients with thalassemia. As well as, increase $\mathrm{HbF}$ lead to reduce balance between alpha and beta chain (due to beta chain production is plague) this results reduction of red blood cell destroyed (62). Some chemicals and drugs such as Hydroxia Urea (HU) can induce synthesis of fetal hemoglobin in adults. Studies show that HU treatment was effective on increasing gamma globin and effective for beta-thalassemia and improve clinical and hematological symptoms in thalassemia intermedia $(63,64)$.

\section{Hematopoietic stem cell transplantation}

Stem cell transplantation is an accepted treatment for thalassemia major (65). In this treatment, stem cells isolated from the bone marrow of healthy individuals, transferred to patients this method is used in the treatment of many diseases such as thalassemia. The treatment was successful in nearly 80 percent of transplant recipients (66). The way to find eligible donor, is examined with transplant recipients according to human leukocyte antigens (HLA). What more agreeable between them, success increases in transplantation and don't reject it. But the most important and dangerous problem in bone marrow transplantation called tansplantation called graft versus host disease (GVHD), which in the end leads to death in transplant recipients $(67,68)$.

\section{Maintenance Treatment}

\section{Chelators therapy}

One of the main treatments is for patients who receive blood. These factors play an important role in Back toxicity of Iron overload is. However, these drugs can produce side effects on the nervous system, their smell and hearing. The intravenous chelating can be noted deferoxamine and oral chelating such deferiprone (69).

\section{Induction of fetal hemoglobin production}

It is observed that people with fetal hemoglobin expression is long term, increases lifespan of red blood cells. This forms the basis of this type of treatment. The following drugs have been used for this purpose (70).

\section{Hydroxiaurea}

The first effects of hydroxyurea were found in patients with sickle cell disease (71). After discovering the fact that hydroxyurea increased gamma-globin it was used in the treatment of thalassemia (72). Hydroxyurea is a ribonucleotide reductase inhibitor and act as a cytotoxic agent for synthesis phase of the cell cycle (73). For the treatment of sickle cell anemia has been tested successfully. It acts as increasing fetal hemoglobin for treatment. Studies of several center determine to use hydroxyurea, is reduced period of bedridden due to acute pain of thorax and necessity to blood transfusion in sickle cell anemia. After two years of treatment beginning, the total amount of fetal hemoglobin increases from 5\% to $9 \%$ in the majority of patients. Along with increasing fetal hemoglobin, decreases sickle hemoglobin polymerization rate. At 9 years of follow-up, 233 cases were identified by medical examiner, has decreased that up to $40 \%$ of deaths. Several different mechanisms have been proposed to increase fetal hemoglobin $(74,75)$.

Since hydroxyurea destroys terminal progenitor cells directly and produce erythroid cells rapidly. So it is suggested this is due to impaired maturation of erythroid precursors. Accelerated hematopoietic causes to increase the immature line commitment and induce the formation of cells contain hemoglobin fetus. Hydroxyurea increases the amount of erythropoietin and progenitor cells can be induced proliferation. The mechanism of action listed for Hydroxyurea can be included in this category $(76,77)$. It is reported that increased fetal hemoglobin 
Thalassemia an update

expression may be due to increased expression of GATA-2 and reduction of expression of GATA-1. Hydroxyurea could also lead to regulation of gene expression related to cell cycle and apoptosis(78). Hydroxyurea performance is related to its concentration. Induction of peroxidation by hydroxyurea can induce nitric oxide (NO). Nitric oxide is a known inducer soluble guanylate cyclase. This plays a role in increase in fetal hemoglobin (79). A GTP-binding protein called SAR specified as inductive particular gene is regulated under Hydroxyurea $(78,80)$.

\section{Factors of hypo-methylation}

These compounds, such Azacytidine compounds also caused switch adult hemoglobin to fetus but as butyrate and hydroxyurea have much their clinical side effects, especially Azacytidine is a major core structural change (81). 5-Azacytidine is first type of agents known to increase fetal hemoglobin. These drugs do their activity through gene silencing in epigenetic (82). The drug was used as an anti-cancer agent for the first time in the United States in the '70s, then, it was applied in patients with hemoglobin disorders in the '80s (83). already used as a treatment for MDS patients (84). 5- Azacytidine has ability to stimulate the production of fetal hemoglobin in anemia monkey was studied for the first time. This was associated with an increased $70-80$ percent of total hemoglobin. This study became basis for other studies that hypometylasion DNA can be used as a setup for expression of fetal hemoglobin in vivo function. This successfully data provide clinical trial studies to use to treat for hemoglobin disorders. In patients with sickle cell and thalassemia, treatment lead to a significant increase in the amount of fetal hemoglobin. This manifests 7 to 23 percent increase in fetal hemoglobin, 11 to 50 percent of cells containing fetal hemoglobin and total hemoglobin 1 to 4 grams per deciliter, respectively. Therapeutic effects were associated with the reduction of sickle cells in sickle cell anemia, reduction of imbalances chains $\beta, \alpha$, and decrease the need for blood transfusions in beta-thalassemia. Despite the promising data from experimental clinical studies were not continued, because shall be considered some carcinogenic effects of this matter. Tumors have been demonstrated in animal models $(61,85)$.

\section{Hemin}

In vitro Hemin stimulates the production of hemoglobin fetus. Which can cause side effects such as phlebitis (inflammation and spasm in veins) noted (86).

\section{Antioxidants}

Free radicals play a role in the pathophysiology of damage to the red blood cell membrane. The use of antioxidants can block the effect. The release of small amounts of iron may trigger oxidation-reduction reactions and reduced regenerative capacity of cells. The use of vitamins $\mathrm{C}$ and $\mathrm{E}$ as antioxidant have been studied greatly (87).

\section{Immunomodulator agents}

Pomalidomide and Lenalidomide can be increased gamma gene expression without any cytotoxic effect other the inducer compounds. In fact, these two drugs are immunomodulatory drugs that reduce the production TNF- $\alpha$. Pomalidomide induce the production of hemoglobin $\mathrm{F}$ stronger than other drugs. It has epigenetic effects like Butyrate (88). It doesn't cause increase expression of the alpha gene that is very important in thalassemia patients. Thalidomide is an Immunomodulatory drug, which is main treatment in multiple myeloma and has good effects on induction of hemoglobin $\mathrm{F}$ and it has mechanisms similar to previous two drugs (89). Of course, this drug has a strong teratogenic and this is limited in application $(90,91)$.

\section{Molecular Therapy}

Due to the adverse effects of drugs in increase $\mathrm{HbF}$, new therapeutic approach suggest to increase in hemoglobin $\mathrm{F}$, which includes molecular targets for induction of alpha hemoglobin F. In fact, this therapeutic approach bears, molecules that play a role in regularity expression gene hemoglobin $\mathrm{F}$ and class switching beta chain and require to correctly understand these pathways. Here described some of the molecules (92).

\section{B-Cell Lymphoma / Leukemia (BCL11A)}

This involve as a growth factor in the production of Blymphocytes. This factor has a low expression when erythroid cells greatly express gamma chain and hemoglobin $\mathrm{F}$ in embryonic early hematopoiesis and liver hematopoiesis (93).

This factor silences gamma chain by banding to GATA-1 and NURD set. In fact, these factors have a direct role in the class switching gamma to beta chain and silencing the expression of the gamma chain (94). Inhibition of its expression using siRNA in blood progenitor cells in adults cause to increase the expression of hemoglobin F (95).

\section{EKLF.1}

It is a major factor in the maturation of red blood cells. This factor normally sticks CACCC sequences in the 
Thalassemia an update

globin promoter region and increases its expression and silencing gamma chain and class switching the chain of gamma to beta $(93,96)$. Two methods include direct and indirectly through the increased expression of BCL11A and thus silencing gamma chain (95). So, inhibition of this factor by siRNA can be increased $\mathrm{HbF}$.

\section{SOX-6}

A factor that normally plays a role in erythropoiesis and the silencing of gamma chain by siRNA that increased gamma chain (97).

\section{MYB}

it is a requirement factor in normal erythropoiesis that reduces expression gamma chain. Increased expression of MYB in K-562 cells resulted in decreased expression of the gamma chain. In trisomy 13 was also referred to the relationship MYB and hemoglobin F. The disease has been found that increased expression of $\mathrm{HbF}$ associated with increased expression of miR-15a/16-1, which increase expression of microRNA lead to direct inhibition MYB and increase $\operatorname{HbF}(70,98)$.

\section{Ikaros}

It is a factor that is predominantly expressed in hematopoietic cells in adult. This factor is in PYR set and it has a role as sub-units binding this set to DNA, silencing gamma chain and switching gamma to beta and. Lack expression of Ikaros (IK -/-) lead to increase expression $\mathrm{HbF}$ in mice (99).

\section{Direct Repeat Erythroid Definitive (DRED)}

This factor is formed from two subunits, TR2 and TR4. This factor has a high binding affinity to DR-1, the alpha and gamma globin in the promoter region, and has the inhibitory effect and lead to off the two chains, but the promoter of beta globin is lacking in this place. As a result of inhibition of this factor using SiRNA can be increased HbF (100).

\section{Stage Selector Protein (SSP)}

This is formed from two subunits, CP2 and P22NFE4. SSP has a high affinity to connect to the motif SSE in gamma-globin promoter and lead to increase gamma chain expression. Increase P22NF-E4 expression, Increased the expression of gamma chain and the delay in beta-gamma class switching in cell line K562 (101).

\section{Acknowledgements}

Thanks to the assistance of the Kurchistan University Thanks to the assistance of the Kurdistan University of Medical Sciences (Cancer and Immunology Research Center)

\section{Author Contributions}

All the authors have accepted responsibility for the entire content of this submitted manuscript and approved submission.

\section{Conflict of interest}

The authors declare that they have no conflict of interest.

\section{Funding/Support}

None declared.

\section{References}

1. Birgens H, Ljung R. The thalassaemia syndromes. Scandinavian journal of clinical and laboratory investigation. 2007;67(1):11-26.

2. Ingram V, Stretton A. Genetic basis of the thalassaemia diseases. Nature. 1959;184:1903-9.

3. Flint J, Harding RM, Boyce AJ, Clegg JB. 1 The population genetics of the haemoglobinopathies. Baillière's clinical haematology. 1998;11(1):1-51.

4. Vichinsky EP. Changing patterns of thalassemia worldwide. Annals of the New York Academy of Sciences. 2005;1054(1):18-24.

5. Taher A, Vichinsky E, Musallam K, Cappellini M, Viprakasit V. Thalassemia International Federation. Guidelines for the management of non-transfusion dependent thalassaemia (NTDT). Thalassaemia International Federation, Nicosia, Cyprus Available at: http://www thalassaemia org cy/wpcontent/uploads/pdf/educationalprogrammes/Publications/Non-Transfusion $\%$ 20Dependent\% 20Thalassaemias. 2013;20(282013):29.

6. Rahim F, Abromand M. Spectrum of B-Thalassemia mutations in various Ethnic Regions of Iran. PAKISTAN Journal of Medical Sciences. 2008;24(3):410.

7. Giardine B, van Baal S, Kaimakis P, Riemer C, Miller W, Samara M, et al. HbVar database of human hemoglobin variants and thalassemia mutations: 2007 update. Human Mutation. 2007;28(2):206-.

8. Hardison RC, Chui DH, Giardine B, Riemer C, Patrinos GP, Anagnou N, et al. HbVar: a relational database of human hemoglobin variants and thalassemia mutations at the globin gene server. Human mutation. 2002;19(3):22533.

9. Galanello R, Cao A. Relationship between Genotype and Phenotype: Thalassemia Intermediaa. Annals of the New York Academy of Sciences. 1998;850(1):325-33.

10. Pagon RA, Adam MP, Ardinger HH, Bird TD, Dolan CR, Fong C-T, et al. Beta-Thalassemia. 2013. 
Thalassemia an update

11. Maakaron JE, Cappellini MD, Taher AT. An update on thalassemia intermedia. Le Journal medical libanais The Lebanese medical journal. 2012;61(3):175-82.

12. Origa R. Beta-Thalassemia. Genetics in Medicine, 2017, 19.6: 609 .

13. Origa R, Moi P, Galanello R, Cao A. Alpha-thalassemia. 2013.

14. Mahdavi M, Kowsarian M, Karami H, Mohseni A, Vahidshahi K, Roshan P, et al. Prevalence of hemoglobin alpha-chain gene deletion in neonates in North of Iran. Eur Rev Med Pharmacol Sci. 2010;14(10):871-5.

15. Reyes-Núñez V, Garcés-Eisele J, Jorge S, Kimura E, Ferreira-Costa F, de Fátima Sonati M, et al. Molecular characterization of alpha-thalassemia in the Mexican population. Revista de investigación clínica. 2006;58(3):234.

16. Zimmer E, Martin S, Beverley S, Kan Y, Wilson AC. Rapid duplication and loss of genes coding for the alpha chains of hemoglobin. Proceedings of the National Academy of Sciences. 1980;77(4):2158-62.

17. Muncie Jr HL, Campbell J. Alpha and beta thalassemia. American family physician. 2009;80(4):339-44.

18. Tang DC, Fucharoen S, Ding I, Rodgers GP. Rapid differentiation of five common $\alpha$-thalassemia genotypes by polymerase chain reaction. Journal of Laboratory and Clinical Medicine. 2001;137(4):290-5.

19. Galanello R, Origa R. Beta-thalassemia. Orphanet journal of rare diseases. 2010;5(1):1.

20. Papakonstantinou O, Drakonaki EE, Maris T, Vasiliadou A, Papadakis A, Gourtsoyiannis N. MR imaging of spleen in beta-thalassemia major. Abdominal imaging. 2015;40(7):2777-82.

21. Taher A, Vichinsky E, Musallam K, Cappellini M, Viprakasit V. Guidelines for the Clinical Management of Non-Transfusion Dependent Thalassaemia (NTDT). ed. D. Weatherall; 2013.

22. Trivedi DJ, Sagare A. Assessment of Iron Overload in Homozygous and Heterozygous Beta Thalassemic Children below 5 Years of Age. Journal of Krishna Institute of Medical Sciences (JKIMSU). 2014;3(2).

23. Salama KM, Ibrahim OM, Kaddah AM, Boseila S, Ismail LA, Hamid MMA. Liver enzymes in children with betathalassemia major: Correlation with iron overload and viral hepatitis. Open Access Macedonian Journal of Medical Sciences. 2015;3(2):287.

24. Elalfy MS, Esmat G, Matter RM, Abdel Aziz H, Massoud WA. Liver fibrosis in young Egyptian beta-thalassemia major patients: relation to hepatitis $\mathrm{C}$ virus and compliance with chelation. Ann Hepatol. 2013;12(10):54.

25. Galanello R, Origa R. Beta-thalassemia: Orphanet J Rare Dis. Journal of Continuing Education Topics \& Issues. 2012;14(1):33-4.

26. Keikhaei B, Zandian K, Rahim F. Existence of cord compression in extramedullary hematopoiesis due to beta thalassemia intermedia. Hematology. 2013.

27. Chalevelakis G, Clegg J, Weatherall D. Imbalanced globin chain synthesis in heterozygous beta-thalassemic bone marrow. Proceedings of the National Academy of Sciences. 1975;72(10):3853-7.

28. Ghaffari S. Oxidative stress in the regulation of normal and neoplastic hematopoiesis. Antioxidants \& redox signaling. 2008;10(11):1923-40.
29. Fang J, Menon M, Kapelle W, Bogacheva O, Bogachev O, Houde E, et al. EPO modulation of cell-cycle regulatory genes, and cell division, in primary bone marrow erythroblasts. Blood. 2007;110(7):2361-70.

30. Gregory T, Yu C, Ma A, Orkin SH, Blobel GA, Weiss MJ. GATA-1 and erythropoietin cooperate to promote erythroid cell survival by regulating bcl-xL expression. Blood. 1999;94(1):87-96.

31. Yatim NFM, Rahim MA, Menon K, Al-Hassan FM, Ahmad R, Manocha AB, et al. Molecular Characterization of $\alpha$-and $\beta$-Thalassaemia among Malay Patients. International journal of molecular sciences. 2014;15(5):8835-45.

32. Yin A, Li B, Luo M, Xu L, Wu L, Zhang L, et al. The prevalence and molecular spectrum of $\alpha$-and $\beta$-globin gene mutations in 14,332 families of Guangdong Province, China. PLoS One. 2014;9(2):e89855.

33. Kazazian Jr H, Orkin S, Antonarakis S, Sexton J, Boehm $\mathrm{CD}$, Goff $\mathrm{S}$, et al. Molecular characterization of seven beta-thalassemia mutations in Asian Indians. The EMBO journal. 1984;3(3):593.

34. Arab A, Karimipoor M, Rajabi A, Hamid M, Arjmandi S, Zeinali S. Molecular characterization of $\beta$-thalassemia intermedia: a report from Iran. Molecular biology reports. 2011;38(7):4321-6.

35. Najmabadi H, Karimi-Nejad R, Sahebjam S, Pourfarzad F, Teimourian S, Sahebjam F, et al. The $\beta$-thalassemia mutation spectrum in the Iranian population. Hemoglobin. 2001;25(3):285-96.

36. Hosseinpour Feizi MA, Hosseinpour Feizi AA, Pouladi $N$, Haghi M, Azarfam P. Molecular spectrum of $\beta$ thalassemia mutations in Northwestern Iran. Hemoglobin. 2008;32(3):255-61.

37. Socolovsky M, Murrell M, Liu Y, Pop R, Porpiglia E, Levchenko A. Negative autoregulation by FAS mediates robust fetal erythropoiesis. PLoS Biol. 2007;5(10):e252.

38. Palis J. Ontogeny of erythropoiesis. Current opinion in hematology. 2008;15(3):155-61.

39. Hengartner MO. The biochemistry of apoptosis. Nature. 2000;407(6805):770-6.

40. Heemels M-T, Dhand R, Allen L. The biochemistry of apoptosis. Nature. 2000;407(6805):770-6.

41. Yuan J, Angelucci E, Lucarelli G, Aljurf M, Snyder L, Kiefer C, et al. Accelerated programmed cell death (apoptosis) in erythroid precursors of patients with severe beta-thalassemia (Cooley's anemia)[see comments]. Blood. 1993;82(2):374-7.

42. Pootrakul P, Sirankapracha P, Hemsorach S, Moungsub W, Kumbunlue R, Piangitjagum A, et al. A correlation of erythrokinetics, ineffective erythropoiesis, and erythroid precursor apoptosis in Thai patients with thalassemia. Blood. 2000;96(7):2606-12.

43. Ribeil J-A, Arlet J-B, Dussiot M, Cruz Moura I, Courtois $\mathrm{G}$, Hermine O. Ineffective erythropoiesis in $\beta$ thalassemia. The Scientific World Journal. 2013;2013.

44. Rund D, Rachmilewitz E. $\beta$-Thalassemia. New England Journal of Medicine. 2005;353(11):1135-46.

45. Schrier SL, Centis F, Verneris M, Ma L, Angelucci E. The role of oxidant injury in the pathophysiology of human thalassemias. Redox report. 2013. 
Thalassemia an update

46. Musallam KM, Cappellini MD, Wood JC, Taher AT. Iron overload in non-transfusion-dependent thalassemia: a clinical perspective. Blood reviews. 2012;26:S16-S9.

47. Hershko C, Link G, Cabantchik I. Pathophysiology of Iron Overloada. Annals of the New York Academy of Sciences. 1998;850(1):191-201.

48. Malik S, Syed S, Ahmed N. Complications in transfusion-dependent patients of $\beta$-thalassemia major. Pak J Med Sci. 2009;25(4):678-82.

49. Aessopos A, Farmakis D. Pulmonary Hypertension in $\beta$ Thalassemia. Annals of the New York Academy of Sciences. 2005;1054(1):342-9.

50. Anthi A, Orfanos SE, Armaganidis A. Pulmonary hypertension in $\beta$ thalassaemia. The Lancet Respiratory Medicine. 2013;1(6):488-96.

51. Aessopos A, Berdoukas V, Tsironi M. The heart in transfusion dependent homozygous thalassaemia todayprediction, prevention and management. European journal of haematology. 2008;80(2):93-106.

52. Toumba M, Sergis A, Kanaris C, Skordis N. Endocrine complications in patients with Thalassaemia Major. Pediatric endocrinology reviews. 2007;5(2):642.

53. De Sanctis V, Eleftheriou A, Malaventura C. Prevalence of endocrine complications and short stature in patients with thalassaemia major: a multicenter study by the Thalassaemia International Federation (TIF). Pediatric endocrinology reviews: PER. 2004;2:249-55.

54. Shamshirsaz AA, Bekheirnia MR, Kamgar M, Pourzahedgilani N, Bouzari N, Habibzadeh $M$, et al. Metabolic and endocrinologic complications in betathalassemia major: a multicenter study in Tehran. BMC Endocrine Disorders. 2003;3(1):1.

55. Cunningham MJ, Macklin EA, Neufeld EJ, Cohen AR, Network TCR. Complications of $\beta$-thalassemia major in North America. Blood. 2004;104(1):34-9.

56. Cappellini MD, Musallam KM, Marcon A, Taher AT. Coagulopathy in beta-thalassemia: current understanding and future perspectives. Mediterranean journal of hematology and infectious diseases. 2009;1(1).

57. Eldor A, Durst R, Hy-Am E, Goldfarb A, Gillis S, Rachmilewitz E, et al. A chronic hypercoagulable state in patients with $\beta$-thalassaemia major is already present in childhood. British journal of haematology. 1999;107(4):739-46.

58. Okada S, Taketa K, Ishikawa T, Koji T, Swe T, Win N, et al. High prevalence of hepatitis $\mathrm{C}$ in patients with thalassemia and patients with liver diseases in Myanmar (Burma). Acta Medica Okayama. 2000;54(3):137-8.

59. Bielinski B, Darbyshire P, Mathers L, Boivin C, Shaw N. Bone density in the Asian thalassaemic population: a cross-sectional review. Acta Paediatrica. 2001;90(11):1262-6.

60. Saffari F, Abolfazl M. Bone mineral density in patients with Beta-Thalassemia Major in Qazvin. Journal of Isfahan Medical School. 2008;26(89):175 82.

61. Thein SL. The emerging role of fetal hemoglobin induction in non-transfusion-dependent thalassemia. Blood reviews. 2012;26:S35-S9.

62. Musallam KM, Taher AT, Cappellini MD, Sankaran VG. Clinical experience with fetal hemoglobin induction therapy in patients with $\beta$-thalassemia Tari et al. 2013;121(12):2199-212.

63. Ansari SH, Lassi ZS, Ali SM, Adil SO, Shamsi TS. Hydroxyurea for $ß$-thalassaemia major. The Cochrane Library. 2016.

64. Fard AD, Hosseini SA, Shahjahani M, Salari F, Jaseb K. Evaluation of novel fetal hemoglobin inducer drugs in treatment of $\beta$-hemoglobinopathy disorders. International journal of hematology-oncology and stem cell research. 2013;7(3):47-54.

65. Angelucci E, Matthes-Martin S, Baronciani D, Bernaudin F, Bonanomi S, Cappellini MD, et al. Hematopoietic stem cell transplantation in thalassemia major and sickle cell disease: indications and management recommendations from an international expert panel. Haematologica. 2014;99(5):811-20.

66. Bernardo ME, Piras E, Vacca A, Giorgiani G, Zecca M, Bertaina A, et al. Allogeneic hematopoietic stem cell transplantation in thalassemia major: results of a reducedtoxicity conditioning regimen based on the use of treosulfan. Blood. 2012;120(2):473-6.

67. Mathews V, George B, Viswabandya A, Abraham A, Ahmed R, Ganapule A, et al. Improved clinical outcomes of high risk $\beta$ thalassemia major patients undergoing a HLA matched related allogeneic stem cell transplant with a treosulfan based conditioning regimen and peripheral blood stem cell grafts. PloS one. 2013;8(4):e61637.

68. King A, Shenoy S. Evidence-based focused review of the status of hematopoietic stem cell transplantation as treatment of sickle cell disease and thalassemia. Blood. 2014;123(20):3089-94.

69. Kwiatkowski JL. Real-world use of iron chelators. ASH Education Program Book. 2011;2011(1):451-8.

70. Wilber A, Nienhuis AW, Persons DA. Transcriptional regulation of fetal to adult hemoglobin switching: new therapeutic opportunities. Blood. 2011;117(15):3945-53.

71. Voskaridou E, Christoulas D, Bilalis A, Plata E, Varvagiannis K, Stamatopoulos G, et al. The effect of prolonged administration of hydroxyurea on morbidity and mortality in adult patients with sickle cell syndromes: results of a 17-year, single-center trial (LaSHS). Blood. 2010;115(12):2354-63.

72. El-Beshlawy A, Hamdy M, El Ghamrawy M. Fetal globin induction in $\beta$-thalassemia. Hemoglobin. 2009;33(sup1):S197-S203.

73. Krakoff IH, Brown NC, Reichard P. Inhibition of ribonucleoside diphosphate reductase by hydroxyurea. Cancer Research. 1968;28(8):1559-65.

74. McGann PT, Ware RE. Hydroxyurea therapy for sickle cell anemia. Expert opinion on drug safety. 2015;14(11):1749-58.

75. Zargari O, Kimyai-Asadi A, Jafroodi M, Chaine B, Neonato M, Girot R, et al. Hydroxyurea for Sickle Cell Anemia. N Engl J Med. 2008;2008(359):98-9.

76. Platt O, Orkin S, Dover G, Beardsley G, Miller B, Nathan D. Hydroxyurea enhances fetal hemoglobin production in sickle cell anemia. Journal of Clinical Investigation. 1984;74(2):652.

77. Ramamurthi A, Devaraj J, Ramkrishna D. Monitoring Hydroxyurea Treatment Of Sickle Cell Anemia. 2014.

78. Tang DC, Zhu J, Liu W, Chin K, Sun J, Chen L, et al. The hydroxyurea-induced small GTP-binding protein SAR 
Thalassemia an update

modulates $\gamma$-globin gene expression in human erythroid cells. Blood. 2005;106(9):3256-63.

79. King SB. Nitric oxide production from hydroxyurea. Free Radical Biology and Medicine. 2004;37(6):737-44.

80. McGann PT, Ware RE. Hydroxyurea for sickle cell anemia: what have we learned and what questions still remain? Current Opinion in Hematology. 2011;18(3):158.

81. Ley TJ, DeSimone J, Anagnou NP, Keller GH, Humphries RK, Turner PH, et al. 5-Azacytidine selectively increases $\gamma$-globin synthesis in a patient with $\beta+$ thalassemia. New England Journal of Medicine. 1982;307(24):1469-75.

82. Lowrey $\mathrm{CH}$, Nienhuis AW. Treatment with azacitidine of patients with end-stage $\beta$-thalassemia. New England Journal of Medicine. 1993;329(12):845-8.

83. Von Hoff DD, Slavik M, Muggia FM. 5-Azacytidine: a new anticancer drug with effectiveness in acute myelogenous leukemia. Annals of Internal Medicine. 1976;85(2):237-45.

84. LuĖbbert M, Wijermans P, Kunzmann R, Verhoef G, Bosly A, Ravoet C, et al. Cytogenetic responses in highrisk myelodysplastic syndrome following low-dose treatment with the DNA methylation inhibitor 5-aza-2'deoxycytidine. British Journal of Haematology. 2001;114(2):349-57.

85. Lavelle D, Saunthararajah Y, Vaitkus K, Singh M, Banzon V, Phiasivongsva P, et al. S110, a novel decitabine dinucleotide, increases fetal hemoglobin levels in baboons (P. anubis). Journal of Translational Medicine. 2010;8(1):1.

86. Fibach E, Kollia P, Schechter A, Noguchi C, Rodgers G. Hemin-induced acceleration of hemoglobin production in immature cultured erythroid cells: preferential enhancement of fetal hemoglobin. Blood. 1995;85(10):2967-74.

87. Scott MD, Eaton JW. Thalassaemic erythrocytes: cellular suicide arising from iron and glutathione-dependent oxidation reactions? British Journal of Haematology. 1995;91(4):811-9.

88. Moutouh-de Parseval LA, Verhelle D, Glezer E, JensenPergakes K, Ferguson GD, Corral LG, et al. Pomalidomide and lenalidomide regulate erythropoiesis and fetal hemoglobin production in human CD34+ cells. The Journal of clinical investigation. 2008;118(1):248-58.

89. Masera N, Tavecchia L, Capra M, Cazzaniga G, Vimercati C, Pozzi L, et al. Optimal response to thalidomide in a patient with thalassaemia major resistant to conventional therapy. Blood Transfus. 2010;8(1):63-5.

90. Meiler SE, Wade M, Kutlar F, Yerigenahally SD, Xue Y, Moutouh-de Parseval LA, et al. Pomalidomide augments fetal hemoglobin production without the myelosuppressive effects of hydroxyurea in transgenic sickle cell mice. Blood. 2011;118(4):1109-12.

91. Dehghani-Fard A, Kaviani S, Saki N, Mortaz E. The emerging role of immunomodulatory agents in fetal hemoglobin induction. International Journal of Hematology-Oncology and Stem Cell Research. 2015;6(4):35-6.

92. Quek L, Thein SL. Molecular therapies in $\beta$ thalassaemia. British Journal of Haematology. 2007;136(3):353-65.
93. Sankaran VG, Menne TF, Xu J, Akie TE, Lettre G, Van Handel B, et al. Human fetal hemoglobin expression is regulated by the developmental stage-specific repressor BCL11A. Science. 2008;322(5909):1839-42.

94. Zhou D, Liu K, Sun C-W, Pawlik KM, Townes TM. KLF1 regulates BCL11A expression and [gamma]-to [beta]-globin gene switching. Nature Genetics. 2010;42(9):742-4.

95. Bradner JE, Mak R, Tanguturi SK, Mazitschek R, Haggarty SJ, Ross K, et al. Chemical genetic strategy identifies histone deacetylase 1 (HDAC1) and HDAC2 as therapeutic targets in sickle cell disease. Proceedings of the National Academy of Sciences. 2010;107(28):1261722.

96. Satta S, Perseu L, Moi P, Asunis I, Cabriolu A, Maccioni $\mathrm{L}$, et al. Compound heterozygosity for KLF1 mutations associated with remarkable increase of fetal hemoglobin and red cell protoporphyrin. Haematologica. 2011;96(5):767-70.

97. Sankaran VG, Xu J, Byron R, Greisman HA, Fisher C, Weatherall DJ, et al. A functional element necessary for fetal hemoglobin silencing. New England Journal of Medicine. 2011;365(9):807-14.

98. Jiang J, Best S, Menzel S, Silver N, Lai MI, Surdulescu $\mathrm{GL}$, et al. cMYB is involved in the regulation of fetal hemoglobin production in adults. Blood. 2006;108(3):1077-83.

99. Lopez RA, Schoetz S, DeAngelis K, O'Neill D, Bank A. Multiple hematopoietic defects and delayed globin switching in Ikaros null mice. Proceedings of the National Academy of Sciences. 2002;99(2):602-7.

100. Tanabe O, Katsuoka F, Campbell AD, Song W, Yamamoto M, Tanimoto K, et al. An embryonic/fetal $\beta$ type globin gene repressor contains a nuclear receptor TR2/TR4 heterodimer. The EMBO journal. 2002;21(13):3434-42.

101. Jane SM, Nienhuis AW, Cunningham JM. Hemoglobin switching in man and chicken is mediated by a heteromeric complex between the ubiquitous transcription factor CP2 and a developmentally specific protein. The EMBO Journal. 1995;14(1):97-105. 